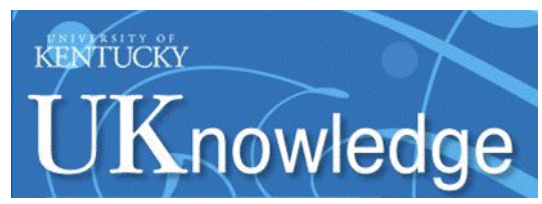

University of Kentucky

UKnowledge

$11-9-2020$

\title{
Atmospheric Measurements with Unmanned Aerial Systems (UAS)
}

Marcelo I. Guzman

University of Kentucky, marcelo.guzman@uky.edu

Follow this and additional works at: https://uknowledge.uky.edu/chemistry_facpub

Part of the Atmospheric Sciences Commons, Chemistry Commons, Environmental Engineering Commons, Environmental Monitoring Commons, and the Fluid Dynamics Commons

Right click to open a feedback form in a new tab to let us know how this document benefits you.

\section{Repository Citation}

Guzman, Marcelo I., "Atmospheric Measurements with Unmanned Aerial Systems (UAS)" (2020).

Chemistry Faculty Publications. 169.

https://uknowledge.uky.edu/chemistry_facpub/169

This Editorial is brought to you for free and open access by the Chemistry at UKnowledge. It has been accepted for inclusion in Chemistry Faculty Publications by an authorized administrator of UKnowledge. For more information, please contact UKnowledge@lsv.uky.edu. 


\section{Atmospheric Measurements with Unmanned Aerial Systems (UAS)}

Digital Object Identifier (DOI)

https://doi.org/10.3390/atmos11111208

\section{Notes/Citation Information}

Published in Atmosphere, v. 11, issue 11, 1208.

(C) 2020 by the author. Licensee MDPI, Basel, Switzerland.

This article is an open access article distributed under the terms and conditions of the Creative Commons Attribution (CC BY) license (https://creativecommons.org/licenses/by/4.0/). 


\title{
Atmospheric Measurements with Unmanned Aerial Systems (UAS)
}

\author{
Marcelo I. Guzman (1) \\ Department of Chemistry, University of Kentucky, Lexington, KY 40506, USA; marcelo.guzman@uky.edu; \\ Tel.: +1-(859)-323-2892
}

Received: 24 October 2020; Accepted: 5 November 2020; Published: 9 November 2020

\section{Introduction}

This Special Issue provides the first literature collection focused on the development and implementation of unmanned aircraft systems (UAS) and their integration with sensors for atmospheric measurements on Earth. The research covered in the Special Issue combines chemical, physical, and meteorological measurements performed in field campaigns as well as conceptual and laboratory work. Useful examples for the development of platforms and autonomous systems for environmental studies are provided, which demonstrate how careful the operation of sensors aboard UAS must be to gather information for remote sensing in the atmosphere. The work serves as a key collection of articles to introduce the topic to new researchers interested in the field, guide future studies, and motivate measurements to improve our understanding of Earth's complex atmosphere. The next section summarizes the key information of individual contributions.

\section{Summary of This Special Issue}

The changing atmospheric composition by emitted greenhouse gases (GHGs) constitutes one of the major challenges faced by societies, and the contribution of UAS to study this problem [1] is the subject of the opening article of this Special Issue. The article revised the use of UAS to accurately report sources and magnitudes of GHGs emission at low altitudes $(<100 \mathrm{~m})$ with spatiotemporal resolution on the order of meters and seconds [1]. The most relevant classes of UAS were evaluated for the operation of gas detectors such as laser-absorption techniques, and metal-oxide semiconductor and catalytic sensors. Special emphasis was provided to explain the importance of calibration and validation of lightweight analytical systems mounted on UAS for quantifying atmospheric gases [1] and thermodynamic parameters [2]. Relevant limits of detection and range for measurements of ozone, carbon monoxide, carbon dioxide, nitrogen dioxide, sulfur dioxide, methane, and volatile organic compounds were provided [1].

As one of the most important and rapidly increasing GHGs, methane can leak to the atmosphere from natural gas systems. Golston et al. and Yang et al. provided an innovative method and algorithm for locating and quantifying continuous leaks as low as 2 standard cubic feet of methane per hour with an UAS equipped with a methane sensor [3,4]. Careful considerations for sampling, i.e., wind effects, variable leak magnitudes, etc., as well as validation of the method and errors were discussed $[3,4]$. Cost considerations for the implementation of UAS with sensors for atmospheric studies were evaluated together with the regulations to operate small UAS internationally to study atmospheric composition [1].

Recent progress in sensor integration and location highlights the importance of sample aspiration and solar shielding, calibration/validation, and vehicle operation for boundary layer profiling for large collaborations [2]. Furthermore, Hemingway et al. discussed an effective strategy to sample vertical profiles with UAS for collecting information on physical variables, i.e., temperature ( $3 \mathrm{~m})$ and humidity 
( $2 \mathrm{~m}$ ) in the atmospheric boundary layer (ABL) [5]. A recent field study by Zhou et al. compared the results from UAS measurements to ground-based stations and satellite remote sensing platforms, to assess the mechanisms for a pollution episode in the city of Nanjing, China [6]. Computational fluid dynamics (CFD) simulations contributed to optimize the mounting location of sensors to minimize air disturbance by propellers [6]. Meteorological conditions that favor the accumulation of particulate matter with diameter $\leq 2.5 \mu \mathrm{m}$ (PM2.5) were identified for long distance transport of pollutants from the Beijing-Tianjin-Hebei region [6].

A challenge to study the ABL with UAS is determining the turbulent tridimensional (3D) wind vector. An important article of the Special Issue by Witte et al. described the development of an UAS for measuring turbulence in the ABL, which was capable of computing the time-dependent wind speed while flying [7]. For this purpose, a five-hole probe velocity sensor was used to combine data from the different sensors [7]. Rautenberg et al. compared commonly used wind speed and direction estimation algorithms with the direct 3D wind vector measurement using a five-hole probe [8]. An exciting research project for studying the ABL over the Arctic was introduced by Kral et al. [9]. Flight missions with high vertical resolution combined the use of fixed and rotary wing UAS, which were supplemented by ground-based observations of eddy covariance, automatic weather stations and remote sensing instrumentation [9]. Bärfuss et al. introduced a flexible UAS for sampling the ABL with sensors for temperature, humidity, 3D wind vector, position, black carbon, irradiance and atmospheric particles [10]. Finally, challenging the original conception of this Special Issue, an interesting consideration for the use of a sounding rocket alternative platform with a satellite navigation system was provided [11]. Such a platform can enable fast and precise meteorological data acquisition of complete trajectories from 20 to $60 \mathrm{~km}$ altitude [11].

\section{Conclusions}

The eleven contributions of this Special Issue discussed different atmospheric problems and strategies to study them with small UAS. The articles should be of interest to the atmospheric sciences community at large, both for instruction of graduate level courses, and to inspire new research that will improve the current understanding of our atmosphere.

Funding: This work received no external funding.

Conflicts of Interest: The author declares no conflict of interest.

\section{References}

1. Schuyler, T.J.; Guzman, M.I. Unmanned Aerial Systems for Monitoring Trace Tropospheric Gases. Atmosphere 2017, 8, 206. [CrossRef]

2. Jacob, J.D.; Chilson, P.B.; Houston, A.L.; Smith, S.W. Considerations for Atmospheric Measurements with Small Unmanned Aircraft Systems. Atmosphere 2018, 9, 252. [CrossRef]

3. Golston, L.M.; Aubut, N.F.; Frish, M.B.; Yang, S.; Talbot, R.W.; Gretencord, C.; McSpiritt, J.; Zondlo, M.A. Natural Gas Fugitive Leak Detection Using an Unmanned Aerial Vehicle: Localization and Quantification of Emission Rate. Atmosphere 2018, 9, 333. [CrossRef]

4. Yang, S.; Talbot, R.W.; Frish, M.B.; Golston, L.M.; Aubut, N.F.; Zondlo, M.A.; Gretencord, C.; McSpiritt, J. Natural Gas Fugitive Leak Detection Using an Unmanned Aerial Vehicle: Measurement System Description and Mass Balance Approach. Atmosphere 2018, 9, 383. [CrossRef]

5. Hemingway, B.L.; Frazier, A.E.; Elbing, B.R.; Jacob, J.D. Vertical Sampling Scales for Atmospheric Boundary Layer Measurements from Small Unmanned Aircraft Systems (sUAS). Atmosphere 2017, 8, 176. [CrossRef]

6. Zhou, S.; Peng, S.; Wang, M.; Shen, A.; Liu, Z. The Characteristics and Contributing Factors of Air Pollution in Nanjing: A Case Study Based on an Unmanned Aerial Vehicle Experiment and Multiple Datasets. Atmosphere 2018, 9, 343. [CrossRef]

7. Witte, B.M.; Singler, R.F.; Bailey, S.C.C. Development of an Unmanned Aerial Vehicle for the Measurement of Turbulence in the Atmospheric Boundary Layer. Atmosphere 2017, 8, 195. [CrossRef] 
8. Rautenberg, A.; Graf, M.S.; Wildmann, N.; Platis, A.; Bange, J. Reviewing Wind Measurement Approaches for Fixed-Wing Unmanned Aircraft. Atmosphere 2018, 9, 422. [CrossRef]

9. Kral, S.T.; Reuder, J.; Vihma, T.; Suomi, I.; O'Connor, E.; Kouznetsov, R.; Wrenger, B.; Rautenberg, A.; Urbancic, G.; Jonassen, M.O; et al. Innovative Strategies for Observations in the Arctic Atmospheric Boundary Layer (ISOBAR)—The Hailuoto 2017 Campaign. Atmosphere 2018, 9, 268. [CrossRef]

10. Bärfuss, K.; Pätzold, F.; Altstädter, B.; Kathe, E.; Nowak, S.; Bretschneider, L.; Bestmann, U.; Lampert, A. New Setup of the UAS ALADINA for Measuring Boundary Layer Properties, Atmospheric Particles and Solar Radiation. Atmosphere 2018, 9, 28. [CrossRef]

11. Zhou, L.; Sheng, Z.; Fan, Z.; Liao, Q. Data Analysis of the TK-1G Sounding Rocket Installed with a Satellite Navigation System. Atmosphere 2017, 8, 199. [CrossRef]

Publisher's Note: MDPI stays neutral with regard to jurisdictional claims in published maps and institutional affiliations.

(C) 2020 by the author. Licensee MDPI, Basel, Switzerland. This article is an open access article distributed under the terms and conditions of the Creative Commons Attribution (CC BY) license (http://creativecommons.org/licenses/by/4.0/). 